Journal of Telenursing (JOTING)

Volume 3, Nomor 1, Juni 2021

e-ISSN: 2684-8988

p-ISSN: 2684-8996

DOI: https://doi.org/10.31539/joting.v3i1.2074

\title{
STIMULUS TAKTIL KINESTETIK TERHADAP PERUBAHAN FISIOLOGIS BAYI PREMATUR DENGAN PERAWATAN METODE KANGURU
}

\author{
Elvi Febria Marnita ${ }^{1}$ Mayetti $^{2}$, Gusti Revilla ${ }^{3}$ \\ Universitas Andalas ${ }^{1,2,3}$ \\ elvifebriamarnita@gmail.com ${ }^{1}$
}

\begin{abstract}
ABSTRAK
Penelitian ini bertujuan untuk mengetahui pengaruh Stimulus Taktil Kinestetik (STK) terhadap perubahan fisiologis bayi prematur yang memperoleh Perawatan Metode Kanguru (PMK). Desain penelitian yang digunakan adalah Quasi Experiment dengan pretest-posttest two-group design. Sampel yang digunakan adalah sebanyak 39 bayi prematur yang dipilih dengan simple random sampling. Kelompok intervensi 20 bayi prematur dilakukan STK dengan durasi 15 menit dan kelompok kontrol 19 bayi prematur tanpa perlakuan. Pengukuran fisiologis pernafasan, denyut jantung, suhu dan berat badan pada kedua kelompok yang dilakukan hari ke 1 dan hari ke 5. Analisis uji statistik menggunakan Paired t-test dan Independent t-test. Hasil penelitian menunjukkan bahwa ada pengaruh perlakuan STK terhadap penurunan pernafasan, penurunan denyut jantung, peningkatan suhu dan peningkatan berat badan pada kelompok intervensi. Kelompok kontrol tanpa perlakuan menunjukkan ada pengaruh peningkatan suhu dan peningkatan berat badan. Tidak ada perbedaan yang signifikan pada kondisi fisiologis bayi prematur pada kelompok intervensi dan kelompok kontrol. Simpulan, pemberian perlakuan STK pada kelompok intervensi berpengaruh terhadap perubahan fisiologis bayi prematur.
\end{abstract}

Kata Kunci: Perawatan Metode Kanguru, Prematur, Stimulus Taktil Kinestetik

\begin{abstract}
This study aims to determine the Kinesthetic Tactile Stimulus (STK) effect on premature babies' physiological changes who receive Kangaroo Method Care (PMK). The research design used was a Quasi Experiment with a pretest-posttest two-group design. The sample was 39 preterm babies with simple random sampling. The intervention group of 20 preterm infants was given STK with 15 minutes and the control group was 19 preterm infants without treatment. Physiological measurements of respiration, heart rate, temperature and body weight in both groups were carried out on day 1 and day 5. Statistical analysis used Paired t-test and an Independent t-test. The results showed an effect of STK treatment on decreased breathing, decreased heart rate, increased temperature and increased body weight in the intervention group. The untreated control group showed an effect of increasing temperature and increasing body weight. There was no significant difference in preterm infants' physiological condition in the intervention group and the control group. The conclusion is that STK treatment in the intervention group affects the physiological changes of prematur babies.
\end{abstract}

Keywords: Kangaroo Treatment, Prematur, Kinesthetic Tactile Stimulus 


\section{PENDAHULUAN}

Secara global, sekitar 15\% bayi baru lahir memiliki Berat Badan Lahir Rendah (BBLR) akibat kelahiran prematur atau pertumbuhan intrauterin retardasi atau keduanya, dan hingga 70\% kematian neonatal. Data terbaru diperoleh dari penelitian menunjukkan bahwa 24\% bayi lahir dengan prematur (Mazumder et al., 2017). Kelahiran prematur sebagian besar $85 \%$ terkonsentrasi di negara berkembang. Bayi prematur dengan berat badan lahir rendah masih menjadi perhatian utama di negaranegara berkembang (Shah \& Singaraveralan, 2019).

Stimulus Taktil Kinestetik (STK) dan Perawatan Metode Kanguru (PMK) adalah dua teknik non famakologis, jika diberikan sedini mungkin kepada bayi, akan membantu mencegah morbiditas dan mortalitas, meningkatkan pertumbuhan, mengurangi lama rawat di rumah sakit sehingga mengurangi biaya tinggal di rumah sakit. Stimulasi Taktil juga dikenal sebagai pijat, terapi usia tua telah digunakan pada bayi baru lahir untuk meningkatkan kesejahteraan fisik mereka dan terbukti efektif dalam mencegah berbagai morbiditas pada bayi prematur. Jika kedua metode diberikan bersamaan pada bayi prematur, ini dapat membantu mengurangi morbiditas dan mortalitas neonatal dan membantu mengurangi biaya yang sangat besar yang dibutuhkan di rumah sakit untuk pemulangan awal bayi (Shah \& Singaraveralan, 2019)

PMK adalah kontak kulit-kulit secara dini, terus menerus dan berkepanjangan antara ibu dan bayi prematur, pemberian ASI eksklusif, kepulangan dini setelah PMK dimulai dari rumah sakit dengan kelanjutan di rumah dan dukungan serta tindak lanjut yang memadai bagi ibu di rumah. PMK membantu meningkatkan detak jantung, laju pernapasan, mencegah infeksi, meningkatka kualitas tidur, menambah berat badan, meningkatkan pertumbuhan fisik, meningkatkan produksi susu, mengurangi rawat inap dan biaya rawatan di rumah sakit dan mencegah depresi ibu (Shah \& Singaraveralan, 2019; Padila et al., 2018). Penelitian tentang efektifitas H-Hope plus Kinesthetic dengan VCO terhadap berat badan dan panjang badan bayi prematur terbukti lebih efektif dalam meningkatkan berat badan dan panjang badan bayi prematur (Ayuningrum, 2019). Hasil penelitian yang dilakukan Anugerah bahwa terapi sentuh efektif meningkatkan suhu tubuh bayi baru lahir normal sebesar 40,1\% (Anuhgera \& Ritonga, 2018).

Durasi PMK yang dilakukan selama 2 jam memberikan pengaruh lebih baik pada suhu, denyut jantung, laju pernapasan, dan saturasi oksigen bayi dari pada durasi 1 jam (Zahra et al., 2018). Hasil yang sama juga ditunjukkan oleh Purwandari et al., (2019) bahwa terdapat peningkatan suhu tubuh, denyut jantung, saturasi oksigen yang signifikan pada perawatan PMK (Purwandari et al., 2019). Penelitian Farida dan Yuliana terhadap intervensi perawatan PMK selama 4 hari berturut-turut selama 2 jam sehari berpengaruh terhadap kestabilan suhu tubuh bayi dan peningkatan berat badan bayi prematur sebanyak 110 gr (Farida \& Yuliana, 2017).

Menurut Parsa et al., (2018) perawatan KMC/PMK efektif terhadap keberlanjutan parameter fisiologis selama perawatan. Namun hasil menunjukkan bahwa tidak ada perbedaan signifikan yang diamati antara efek PMK dan metode perawatan rutin pada kriteria fisiologis pada bayi berat lahir rendah selama intervensi. Perbedaan yang signifikan terlihat antara dua kelompok dalam hal detak jantung, saturasi oksigen dan laju pernapasan 5 menit setelah intervensi. Pengaruh PMK dan STK terhadap pertambahan berat badan menunjukkan hasil bahwa tidak ada penambahan Berat badan yang signifikan yang dilakukan selama 5 hari. Meskipun demikian bayi mengalami kenaikan berat badan berdasarkan mereka dipulangkan lebih awal dari yang diharapkan. 
Studi tersebut menunjukkan bahwa teknik-teknik ini masih terbukti efektif dan bermanfaat bagi bayi dan keluarganya terutama bila dilakukan bersama-sama (Shah \& Singaraveralan, 2019).

Proporsi bayi prematur di Indonesia sebesar 6,2\%, dimana provinsi tertingi terdapat di Sulawesi Tengah 8,9\%, Maluku utara 8,7\%, sedangkan Sumatera Barat 4,6\% (Kementerian Kesehatan RI, 2018). Data Dinas Kesehatan Kota Padang sebanyak 16.282 bayi yang ditimbang pada tahun 2018, sejumlah 295 orang $(1,81 \%)$ bayi dengan berat badan lahir rendah terdiri dari 140 bayi laki-laki dan 155 bayi perempuan. Jumlah ini mengalami peningkatan dari tahun sebelumnya yaitu $1,50 \%$ atau sebesar 255 orang yaitu 146 bayi laki-laki dan 109 bayi perempuan (Dinkes Padang, 2018). Transisi kehidupan janin pada masa neonatal merupakan hal yang paling dinamis dan sering menimbulkan potensi yang berbahaya di awal siklus kehidupannya. Periode postnatal sering mengakibatkan stress pada bayi baru lahir. Peningkatan sekresi katekolamin dan sekresi kortisol pada bayi baru lahir akan mempengaruhi perubahan perilaku . Oleh karena itu diperlukan tindakan yang dapat meningkatkan stabilitas saraf, perilaku, regulasi dan membantu adaptasi bayi di kehidupan ekstrauterinnya. Terapi sentuhan terbukti meningkatkan kematangan motorik pada bayi prematur. Sentuhan dari kulit ke kulit bermanfaat untuk pengaturan aktivitas motorik pada bayi baru lahir dan menurunkan produksi kortisol pada tubuh bayi (Ferber \& Makhoul, 2018; Padila et al., 2018).

Berdasarkan uraian di atas, penelitian ini akan dilakukan pada bayi prematur usia kelahiran lebih dari 2 minggu dan kecil dari 12 bulan. Bayi prematur yang dilakukan STK adalah bayi yang sudah memperoleh PMK. Parameter pengukuran yang dilakukan berupa pernafasan, denyut jantung, suhu dan berat badan bayi yang dilakukan selama 5 hari berturut turut dengan durasi 1 kali sehari selama 15 menit. Penelitian ini dilakukan untuk mengetahui pengaruh dan perbedaan STK terhadap perubahan fisiologis bayi prematur dengan PMK.

\section{METODE PENELITIAN}

Desain penelitian Quasi Experiment dengan pretest-posttest two group design. Pengambilan sampel dengan simple random sampling 39 bayi prematur. Kelompok intervensi 20 bayi prematur dilakukan Stimulus Taktil Kinestetik dengan durasi 15 menit dan kelompok kontrol 19 bayi prematur tanpa perlakuan. Pengukuran pernafasan, denyut jantung, suhu dan berat badan pada kelompok intervensi dilakukan hari ke 1 dan hari ke 5. Kelompok kontrol tidak diberi perlakuan apapun dilakukan pengukuran pernafasan, denyut jantung, suhu, dan berat badan hari ke 1 dan hari ke 5 .

Analisis yang digunakan berupa distribusi frekuensi untuk variabel jenis kelamin, usia ibu, nutrisi bayi (ASI atau ASI+PASI), pendidikan ibu dan pekerjaan ibu. Untuk karakteristik usia bayi, BB lahir, masa gestasi serta fisiologis bayi disajikan dalam bentuk (mean), standar deviasi. Analisis yang digunakan untuk mengetahui pengaruh Stimulus Taktil Kinestetik terhadap perubahan fisiologis bayi prematur dengan Perawatan Metode Kanguru menggunakan analisis statistik Paired T-test, sedangkan untuk melihat perbedaan Stimulus Taktil Kinestetik terhadap perubahan fisiologis bayi prematur dengan Perawatan Metode Kanguru kedua kelompok menggunakan Independent T-test. 


\section{HASIL PENELITIAN}

Tabel. 1

Distribusi Berdasarkan Karakteristik Ibu Kelompok Intervensi dan Kontrol di RSUD dr. Rasidin Padang dan RS Reksodiwiryo Padang

\begin{tabular}{ccccc}
\hline Karakteristik & Intervensi f $(\%)$ & Kontrol f $(\%)$ & Total f $(\%)$ & P-value \\
\hline Usia Ibu (Tahun) & $6(30)$ & $5(26,3)$ & $11(28,2)$ & \\
$<20$ & $12(60)$ & $12(68,4)$ & $24(61,5)$ & 0,76 \\
$20-35$ & $2(10)$ & $2(21,1)$ & $4(10,3)$ & \\
$>35$ & $12(60)$ & $12(63,2)$ & $24(61,5)$ & \\
\hline Pekerjaan Ibu & $6(30)$ & $5(26,3)$ & $11(28,2)$ & 0,98 \\
IRT & $2(10)$ & $2(10,5)$ & $4(10,3)$ & \\
Wirausaha & $0(0)$ & $0(0)$ & & \\
Pegawai Swasta & $3(15)$ & $2(10,5)$ & $5(12,8)$ & \\
\hline Pendidikan Ibu & $13(65)$ & $13(68,4)$ & $26(66,7)$ & 0,98 \\
Tamat SD & $4(20)$ & $4(21,1)$ & $8(20.5)$ & \\
Tamat SMP & $($ Mean \pm SD) & Mean \pm SD) & \\
Tamat SMA & $34 \pm 1,68$ & $34 \pm 1,53$ & \\
Sarjana & \multicolumn{3}{c}{}
\end{tabular}

Hasil penelitian karakteristik ibu menunjukkan lebih dari separoh rentang usia ibu 20-35 tahun (61,5\%) dan pada pekerjaan ibu lebih banyak sebagai IRT (61,5\%), sebagian besar ibu memiliki pendidikan tamat SMA $(66,7 \%)$ dengan rata-rata masa gestasi kedua kelompok 34 minggu.

Tabel. 2

Distribusi Berdasarkan Karakteristik Bayi Kelompok Intervensi dan Kontrol pada Bayi Prematur di RSUD dr. Rasidin Padang dan RS Reksodiwiryo Padang

\begin{tabular}{ccccc}
\hline Karakteristik & Intervensi f $(\%)$ & Kontrol f $(\%)$ & Total f $(\%)$ & P-value \\
\hline Jenis Kelamin & $12(60)$ & $10(52,6)$ & $22(56,4)$ & 0,44 \\
Laki-Laki & $8(40)$ & $9(47,4)$ & $17(43,6)$ & \\
Perempuan & $17(85)$ & $15(78,9)$ & $32(82,1)$ & 0,34 \\
\hline Nutrisi Bayi & $3(15)$ & $4(21,1)$ & $7(17,9)$ & \\
ASI & $($ Mean \pm SD) & $($ Mean \pm SD) & 0,14 \\
ASI+PASI & $17,90 \pm 2,45$ & $18,05 \pm 1,65$ & 0,26 \\
\hline Usia Bayi (hari) & $2238,30 \pm 180,39$ & $2284,11 \pm$ \\
BBL (gr) & 131,60 & \\
\hline
\end{tabular}

Berdasarkan karakteritik bayi, lebih dari separoh karakteristik bayi diperoleh jenis kelamin laki-laki (56,4\%). Lebih dari separoh mendapat nutrisi dengan ASI $(82,1 \%)$. Pada kelompok intervensi usia bayi rata-rata 17,90 hari $( \pm 2,45)$ dan kelompok kontrol 18,05 hari $( \pm 1,65)$ dengan BB lahir kelompok intervensi rata-rata 2238,30 gr $( \pm 180,39)$ dan kelompok kontrol rata-rata 2284,11 $( \pm 131,60)$. 
Tabel. 3

Rerata Kondisi Fisiologis Bayi Prematur Pre-Post Intervensi dan Kontrol Selama 5

Hari pada Bayi Prematur di RSUD dr. Rasidin Padang dan RS Reksodiwiryo Padang

\begin{tabular}{ccccccccc}
\hline \multirow{3}{*}{ Variabel } & \multicolumn{4}{c}{ Pre-Test } & \multicolumn{4}{c}{ Post-Test } \\
\cline { 2 - 9 } & \multicolumn{2}{c}{ Intervensi } & \multicolumn{2}{c}{ Kontrol } & \multicolumn{2}{c}{ Intervensi } & \multicolumn{2}{c}{ Kontrol } \\
\cline { 2 - 9 } & Mean & SD & Mean & SD & Mean & SD & Mean & SD \\
\hline RR (f) & 45 & 4,23 & 44,11 & 3,81 & 43,95 & 3,66 & 43,79 & 3,33 \\
DJ (f) & 138,20 & 3,93 & 138,32 & 6,08 & 137,15 & 3,66 & 137,84 & 5,57 \\
Suhu ( $\left.{ }^{\circ} \mathrm{C}\right)$ & 36,40 & 0,31 & 36,43 & 0,36 & 36,66 & 0,16 & 36,58 & 0,15 \\
BB (gr) & 2507,5 & 151,82 & 2540,6 & 150,9 & 2611,4 & 145,2 & 2637,5 & 149,9 \\
\hline
\end{tabular}

Hasil penelitian rerata fisiologis bayi prematur menunjukkan bahwa sebelum dan setelah baik pada kelompok intervensi maupun pada kelompok kontrol terlihat penurunan RR dan DJ dan peningkatan suhu dan BB.

Tabel. 4

Perubahan Selisih Rata-Rata Kondisi Fisiologis Bayi Prematur Pre-Post pada Kelompok Intervensi dan Kontrol di RSUD dr. Rasidin Padang dan RS Reksodiwiryo Padang

\begin{tabular}{ccccccc}
\hline Variabel & \multicolumn{3}{c}{ Pre-Post-test Intervensi } & \multicolumn{3}{c}{ Pre-Post-test Kontrol } \\
\cline { 2 - 7 } & \multicolumn{3}{c}{ Differences } & \multicolumn{3}{c}{ Differences } \\
\cline { 2 - 7 } & Mean & SD & P-value & Mean & SD & P-value \\
\hline RR (f) & 1,05 & 1,54 & 0,007 & 0,32 & 1,34 & 0,316 \\
DJ (f) & 1,05 & 1,93 & 0,025 & 0,47 & 1,22 & 0,107 \\
Suhu ( $\left.{ }^{\circ} \mathrm{C}\right)$ & 0,25 & 0,19 & 0,000 & 0,15 & 0,29 & 0,037 \\
BB (gr) & 103,90 & 30,75 & 0,000 & 96,89 & 10,03 & 0,000 \\
\hline
\end{tabular}

Hasil penelitian perubahan selisih rata-rata pada kelompok intervensi menunjukkan adanya pengaruh yang signifikan pada kondisi fisiologis bayi prematur dengan $\mathrm{p}<0,05$. Sedangkan pada kelompok kontrol diperoleh perubahan yang signifikan pada kondisi fisiologis suhu dan $\mathrm{BB} p<0,05$.

Tabel. 5

Perbedaan Selisih Pre-Post Kelompok Intervensi dan Kontrol pada Perubahan Fisiologis Bayi Prematur di RSUD dr. Rasidin Padang dan RS Reksodiwiryo Padang

\begin{tabular}{ccccccc}
\hline \multirow{2}{*}{ Selisih $\Delta$} & \multicolumn{2}{c}{ Intervensi } & \multicolumn{2}{c}{ Kontrol } & \multirow{2}{*}{ Mean } & \multirow{2}{*}{ P-value } \\
\cline { 2 - 5 } & Mean & SD & Mean & SD & Differences & \\
\hline RR (f) & 1,05 & 1,54 & 0,32 & 1,34 & 0,74 & 0,121 \\
DJ (f) & 1,05 & 1,93 & 0,47 & 1,22 & 0,58 & 0,271 \\
Suhu ( $\left.{ }^{\circ} \mathrm{C}\right)$ & 0,25 & 0,19 & 0,15 & 0,29 & 0,09 & 0,226 \\
BB (gr) & 103,90 & 30,75 & 96,89 & 10,03 & 7,01 & 0,344 \\
\hline
\end{tabular}

Hasil penelitian perbedaan selisih fisiologis bayi prematur menunjukkan tidak ada perbedaan yang signifikan selisih kondisi fisiologis bayi prematur terhadap kelompok intervensi dengan kontrol. 


\section{PEMBAHASAN}

\section{Pengaruh Perubahan Selisih Rata-Rata Kondisi Fisiologis Bayi Prematur Pre-Post pada Kelompok Intervensi dan Kontrol Respiratory Rate (RR)}

Hasil penelitian fisiologis pernafasan bayi prematur sebelum rata-rata 45 dan setelah rata-rata 43,95 pada kelompok intervensi mengalami penurunan selisih rata-rata sebesar 1,05 dengan hasil uji Paired t-test signifikan dengan $\mathrm{p}=0,007$. Sedangkan pada kelompok kontrol sebelum rata-rata 44,11 dan setelah rata-rata 43,79 mengalami penurunan selisih rata-rata 0,32. Namun, hasil uji Paired t-test tidak signifikan dengan $\mathrm{p}$ $=0,316$.

Sentuhan yang diberikan akan memberikan respon neuroendokrin pada bayi sehingga menurunkan respon stres yang berdampak terhadap peningkatan respirasi. posisi PMK yang dilakukan akan mempengaruhi ventilasi dan perfusi sehingga dengan posisi tersebut dapat mengoptimalkan pernafasan bayi (Shah \& Singaraveralan, 2019). PMK dapat mengurangi frekuensi napas bayi prematur ini karena posisi bayi vertikal dengan sudut $\pm 60^{\circ}$ dimana menurunkan kompresi diafragma bayi. Ventilasi dan perfusi sangat dipengaruhi oleh gravitasi, sehingga dengan posisi berdiri tersebut dapat mengoptimalkan fungsi sistem respirasi bayi (Zahra et al., 2018).

Penelitian Balushi \& Hanson (2019) menemukan bahwa ada pengaruh yang signifikan pada penurunan laju pernafasan setelah dilakukan pijat bayi dengan rata-rata 1,97 ( $\mathrm{p}=0,05)$. Dalam desain studi kuasi-eksperimental, Ramezani et al., (2017) juga menemukan bahwa ada perbedaan yang signifikan diamati pada penurunan laju pernapasan dengan rata-rata $2,8(\mathrm{P}=0,001)$. Sedangkan penelitian terkait PMK yang dilakukan oleh Zahra et al., (2018) menunjukkan bahwa pengukuran laju pernapasan menunjukkan adanya penurunan $(\mathrm{p}=0,058)$ setelah 1 jam PMK dan $(\mathrm{p}<0,001)$ setelah 2 jam PMK. Hal ini menunjukkan terjadinya penurunan laju pernapasan secara klinis antara sebelum, setelah satu jam, dan setelah dua jam dilakukannya PMK.

Hal ini menunjukkan bahwa dalam penelitian ini bayi prematur yang mendapat intervensi akan terjadi penurunan laju pernafasan dikarenakan sentuhan yang diberikan akan memberikan respon neuroendokrin pada bayi sehingga menurunkan respon stres yang berdampak terhadap peningkatan respirasi. Posisi PMK yang dilakukan akan mempengaruhi ventilasi dan perfusi sehingga dengan posisi tersebut dapat mengoptimalkan pernafasan bayi.

\section{Denyut Jantung}

Hasil penelitian fisiologis DJ bayi prematur sebelum rata-rata 138,20 dan setelah rata-rata 137,15 pada kelompok intervensi mengalami penurunan selisih rata-rata 1,05 dengan hasil uji Paired $t$-test signifikan $\mathrm{p}=0,025$. Pada kelompok kontrol sebelum ratarata 138,32 dan setelah rata-rata 137,84 mengalami penurunan selisih rata-rata 0,47 . Namun, hasil uji Paired t-test tidak signifikan dengan $\mathrm{p}=0,107$.

Penelitian Balushi \& Hanson (2019) menunjukkan bahwa terdapat pengaruh yang signifikan pada penurunan rata-rata denyut jantung setelah dilakukan pijat bayi dengan rata-rata 2,75 ( $\mathrm{p}=0,05)$. Ramezani et al., (2017) mengatakan bahwa ada penurunan yang signifikan pada rata-rata denyut jantung 2,25 $(\mathrm{P}=0,03)$. Sedangkan, penelitian Zahra et al., (2018) tentang pengaruh durasi PMK terhadap perubahan tanda vital bayi berat lahir rendah usia 0-28 hari, telah stabil dan belum pernah dilakukan PMK sebelumnya. Pengukuran denyut jantung menunjukkan penurunan setelah PMK 1 jam $(p=0,054)$ dan setelah PMK 2 jam (p<0,001) (Zahra et al., 2018). 
Perawatan yang dilakukan dengan sentuhan dapat menurunkan respon stres pada bayi. Denyut jantung bayi bekerja lebih stabil akibat dari proses adaptasi intrauterin ke ekstrauterin yang berlebihan menimbulkan stres pada bayi prematur dilakukan perawatan dengan sentuhan lembut melalui Stimulus Taktil Kinestetik untuk menenangkan atau mengurangi efek stres pada bayi prematur, mengingat bahwa mereka mengalami banyak stres selama mereka rawat inap (Field, 2017). PMK efektif untuk menstabilkan fungsi fisiologis bayi prematur (suhu tubuh, detak jantung, pernafasan, saturasi oksigen), meningkatkan ikatan emosional antara ibu dan bayi, bayi lebih mudah mendapatkan ASI secara intensif sehingga Pertumbuhan dan pertambahan berat badan bayi prematur lebih cepat, selain itu pola tidur yang teratur pada bayi diberikan dukungan KMC dalam membantu perkembangan otak dan sekresi yang lebih baik dalam proses pencernaan (Saputri et al., 2019). Hal ini dapat dijelaskan karena selama dilakukan PMK, terjadi bonding antara bayi dengan ibu/ayah bayi, bayi merasa lebih tenang dan nyaman, sehingga frekuensi denyut jantung relatif lebih konstan/ stabil (Wati et al., 2019). Hasil penelitian ini berdasarkan uji statistik diperoleh bahwa ada perubahan yang signifikan sebelum dan setelah dilakukan intervensi, namun berbeda dengan kelompok kontrol dimana denyut jantung tidak ada perubahan yang signifikan.

\section{Suhu Bayi}

Hasil penelitian fisiologis suhu bayi prematur sebelum rata-rata 36,40 dan setelah rata-rata 36,66 pada kelompok intervensi mengalami kenaikkan selisih rata-rata 0,25 dengan hasil uji Paired $t$-test signifikan $\mathrm{p}=0,000$. Pada kelompok kontrol sebelum ratarata 36,43 dan setelah rata-rata 36,58 juga mengalami kenaikan selisih rata-rata 0,15 dengan hasil uji Paired $t$-test signifikan $\mathrm{p}=0,037$.

Penelitian ini berbeda dengan penelitian Balushi \& Hanson (2019) yang menemukan bahwa tidak ada pengaruh yang signifikan pada suhu tubuh setelah dilakukan pijat bayi dengan rata-rata $0,5(\mathrm{p}=0,56)$. Terapi sentuhan berpengaruh signifikan terhadap peningkatan suhu pada bayi baru lahir sebesar 40,1\% (Anuhgera \& Ritonga, 2018). Penelitian yang dilakukan Wati diperoleh peningkatan suhu tubuh bayi sebesar $0,4^{\circ} \mathrm{C}$ ) dan nilai $p$-value 0,002 yang artinya ada pengaruh yang signifikan Perawtan Metode Kanguru terhadap suhu tubuh BBLR (Wati et al., 2019).

Bayi prematur cenderung memiliki suhu yang abnormal disebabkan oleh produksi panas yang buruk dan peningkatan kehilangan panas. Kegagalan untuk menghasilkan panas yang adekuat disebabkan tidak adanya jaringan adiposa coklat (yang mempunyai aktivitas metabolik yang tinggi). Kehilangan panas yang meningkat karena adanya permukaan tubuh yang realtif besar dan tidak adanya lemak subkutan, tidak adanya pengaturan panas bayi sebagian disebabkan oleh panas immature dari pusat pengatur panas, keadaan ini disebabkan oleh mekanisme keringat yang cacat (Padila et al., 2018; Purwandari et al., 2019).

Pemberian terapi sentuhan, bayi baru lahir akan merasa hangat dan menyalurkan energi positif dari terapis ke bayi baru lahir sehingga dapat melancarkan sirkulasi peredaran darah bayi dan meningkatkan suhu tubuh di otak bayi. Bayi yang diberikan terapi sentuhan terlihat lebih nyaman dan kooperatif apabila diajak untuk berinteraksi. Terapi sentuhan terbukti meningkatkan kematangan motorik pada bayi prematur. Sentuhan dari kulit ke kulit bermanfaat untuk pengaturan aktivitas motorik pada bayi baru lahir dan menurunkan produksi kortisol pada tubuh bayi (Ferber \& Makhoul, 2018). Pemberian Stimulus Taktil Kinestetik bersifat sebagai sentuhan halus, sehingga 
dapat meningkatkan perkembangannya yang ditunjukkan salah satunya adalah bayi merasakan hangat.

Mekanisme dari metode kanguru dalam meningkatkan suhu tubuh dilakukan secara konduksi yaitu perpindahan suhu tubuh ibunya secara langsung melalui kontak dari kulit ke kulit mengingat suhu tubuh ibunya lebih tinggi dari suhu tubuh bayi. Peran kulit sebagai termoregulasi meliputi vasokonstriksi yang mempengaruhi jumlah aliran darah dari jantung ke kulit, kehilangan panas dan sensasi tubuh. Kulit, jaringan subkutan dan lemak menyimpan panas di dalam tubuh, jumlah aliran darah yang mengalir dari jantung sampai ke peifer sebanyak 30\% darah yang melalui area kulit yang banyak memiliki pembuluh darah. Panas berpindah dari darah melalui dinding pembuluh darah ke permukaan kulit dan hilang ke lingkungan melalui mekanisme kehilangan panas. Bila suhu inti menjadi terlalu rendah, hypotalamus akan mengalami vasokonstriksi dan aliran darah ke kulit berkurang sehingga kulit akan terasa dingin. Bila ada sensor dingin hypotalamus akan memberikan sinyal untuk menghasilkan produksi panas dan mengurangi pangeluaran panas dengan cara vasokonstriksi, menggigil, dan melepaskan epinefrin, yang meningkatkan metabolisme sel sehingga menyebabkan peningkatan produksi panas (Farida \& Yuliana, 2017).

Kulit merupakan system termoregulator yang baik karena aliran darah ke kulit merupakan mekanisme penyebaran panas yang paling efektif dari suhu inti ke suhu permukaan kulit. Dengan pemberian metode kanguru yang di berikan penulis kepada pasien, proses kehilangan suhu tubuh dengan cara konveksi dan radiasi yang di alami pasien tidak terjadi karena kulit bayi tidak bersentuhan langsung dengan udara yang lebih dingin, tapi bersentuhan dengan kulit ibu yang suhunya lebih panas sehingga memungkinkan terjadinya proses perpindahan panas dari tubuh ibu ke bayi (Farida \& Yuliana, 2017).

Menurut asumsi peneliti STK dan PMK merupakan salah satu cara yang dinilai efektif karena kontak kulit dengan kulit merupakan sebuah metode perawatan bayi yang baru lahir untuk menyalurkan kehangatan pada bayi yang bertujuan untuk mempertahankan suhu bayi tetap normal.

\section{Berat Badan Bayi}

Hasil penelitian BB bayi prematur sebelum rata-rata 2507,50 dan setelah rata-rata 2611,40 pada kelompok intervensi mengalami kenaikkan selisih rata- rata 103,90 gr dengan hasil uji Paired $t$-test signifikan $\mathrm{p}=0,000$. Pada kelompok kontrol sebelum ratarata 2540,53 dan sebelum rata-rata 2637,53 juga mengalami kenaikan BB selisih ratarata 96,89 dengan hasil uji Paired t-test signifikan $\mathrm{p}=0,000$.

Penelitian Balushi \& Hanson (2019) menemukan adanya pengaruh yang signifikan pada pertambahan berat badan sebesar 266,68 gram pada akhir 10 hari penelitian $(\mathrm{p}=0,05)$. Penelitian tentang efektifitas H-Hope plus Kinesthetic dengan VCO terhadap berat badan dan panjang badan bayi prematur terbukti lebih efektif dalam meningkatkan berat badan dan panjang badan bayi prematur (Ayuningrum, 2019). Intervensi perawatan PMK selama 4 hari berturut-turut selama 2 jam sehari juga berpengaruh terhadap kestabilan suhu tubu bayi dan peningkatan berat badan bayi prematur sebanyak 110 gr (Farida \& Yuliana, 2017). Hasil penelitian Shah \& Singaraveralan (2019) memperlihatkan bahwa terdapat pengaruh PMK dan STK terhadap pertambahan berat badan menunjukkan hasil bahwa tidak ada penambahan Berat badan yang signifikan yang dilakukan selama 5 hari. Meskipun demikian bayi mengalami kenaikan berat badan setelah mereka dipulangkan lebih awal dari yang 
diharapkan. Studi tersebut menunjukkan bahwa teknik-teknik ini masih terbukti efektif dan bermanfaat bagi bayi dan keluarganya terutama bila dilakukan bersama-sama.

Melalui pijat bayi, sentuhan disertai dengan penekanan lembut pada bayi akan menyebabkan ujung-ujung saraf yang terdapat di permukaan kulit bereaksi terhadap sentuhan. Selanjutnya, saraf tersebut mengirimkan pesan-pesan ke otak melalui jaringan saraf yang berada di medula spinalis. Proses tersebut dapat menyebabkan perangsangan pada reseptor saraf sensorik perifer terutama reseptor tekanan. Rangsangan ini mengaktifkan sistem saraf parasimpatis. Pemberian pijat bayi akan merangsang nervus vagus yang mengatur fungsi organ tubuh termasuk bagian dada dan perut. Rangsangan pada nervus vagus (saraf parasimpatis) akan merangsang lambung untuk mengeluarkan hormon gastrin. Hormon gastrin akan merangsang pengeluaran insulin, asam hidroklorida, pepsinogen, enzim pankreas, mukus, peningkatan aliran empedu hati dan merangsang motilitas lambung (Shah \& Singaraveralan, 2019).

Mekanisme metode kanguru dalam meningkatkan berat badan bayi terjadi karena bayi dalam keadaan rileks, beristirahat dengan posisi yang menyenangkan, mirip dengan posisi dalam rahim, sehingga kegelisahan bayi berkurang dan tidur lebih lama. Keadaan tersebut mengakibatkan konsumsi oksigen dan kalori berada pada tingkat paling rendah, sehingga kalori yang ada digunakan untuk menaikkan berat badan. Selain itu peningkatan berat badan juga disebabkan oleh frekwensi menyusui yang lebih sering. Pada kasus setelah dilakukan metode kanguru terjadi peningkatan frekuensi ibu dalam memberikan ASI. Karena bayi selalu berada dalam dekapan ibu dan dalam kondisi bila pasien sudah merasa haus dan memerlukan ASI maka pasien akan mencari sendiri puting susu ibu dalam baju kangurunya, sehingga hal ini juga membantu pasien dalam memenuhi kebutuhan akan nutrisi dan cairanya (Farida \& Yuliana, 2017)

\section{Perbedaan Selisih Rata-Rata Pre-Post pada Kelompok Intervensi dan Kontrol pada Perubahan Fisiologis Bayi Prematur}

Hasil penelitian ini ditemukan bahwa tidak ada perbedaan perubahan kondisi fisiologis bayi prematur baik antara kedua kelompok dengan $\mathrm{p}>0,05$. STK dan PMK termasuk kontak skin to skin dimana memberikan efek positif pada perkembangan bayi. Kulit merupakan organ terbesar tubuh dimana terdapat sistem sensorik yang peka terhadap rangsangan. Stimulus yang diberikan akan memicu respon parasimpatis. Keadaan ini dapat dibuktikan dengan penurunan kadar kortisol dalam darah. Efek positif yang didapatkan adalah bayi prematur akan dapat tidur dengan tenang, jarang menangis dan mengalami stres yang levelnya lebih rendah dibandingkan bayi prematur yang tidak mendapat perlakuan. Keadaan ini akan menyebabkan energi tersimpan dan dapat digunakan untuk tumbuh secara optimal (Shah \& Singaraveralan, 2019).

Dalam penelitian ini diperoleh tidak signifikan perbandingan kedua kelompok namun dapat terlihat perbandingan perubahan kondisi bayi yang positif lebih baik diberikan intervensi dari pada kelompok kontrol. Perbandingan yang tidak signifikan bisa saja disebabkan oleh berbagai faktor yang mempengaruhi, seperti efek suhu lingkungan terhadap suhu tubuh, kapasitas ASI yang dikonsumsi bayi, faktor keaktifan bayi terhadap laju pernafasan dan DJ bayi dan berbagai faktor lainnya. 


\section{SIMPULAN}

Intervensi STK dalam penelitian ini menunjukkan hasil yang signifikan terhadap perubahan kondisi fisiologis bayi prematur (pernafasan, denyut jantung, suhu dan BB). Sedangkan pada kelompok kontrol tanpa perlakuan, diperoleh perubahan yang signifikan hanya pada kondisi fisiologis suhu dan BB. Perbandingan selisih kondisi fisiologis bayi prematur pada kelompok intervensi dan kontrol menunjukkan bahwa tidak ada perbedaan yang signifikan.

\section{SARAN}

Diharapkan penelitian STK dan PMK pada bayi prematur dilaksanakan dengan mengontrol lama perlakuan dan jumlah perlakuan yang diberikan serta faktor-faktor yang mempengaruhi hasil pengukuran seperti suhu lingkungan, intake nutrisi bayi dan faktor lainnya yang mempengaruhi pengukuran.

\section{DAFTAR PUSTAKA}

Anuhgera, D. E., \& Ritonga, N. J. (2018). Pengaruh Terapi Sentuh Terhadap Peningkatan Suhu Tubuh pada Bayi Baru Lahir Normal. Jurnal Penelitian Kebidanan \& Kespro, 1(1), 1-5. http://ejournal.delihusada.ac.id/index.php/JPK2R

Ayuningrum, L. D. (2019). H-Hope Plus Kinesthetic With VCO on Weight and Body Length of Preterm Infants. Jurnal Ners dan Kebidanan Indonesia, 6(3), 58. https://doi.org/10.21927/jnki.2018.6(3).58-63

Balushi, S. M. A. A., \& Hanson, V. F. (2019). Effect of Neonatal Massage on Weight Gain and Physical Responses Among Preterm Babies in Selected Hospital in Fujairah United Arab Emirate. International Journal of Nursing, Midwife and Health Related Cases, 5(3), 20-33. https://www.eajournals.org/wpcontent/uploads/Effect-of-Neonatal-Massage-on-Weight-Gain-and-PhysicalResponses-among-Preterm-Babies-in-Selected-Hospital-in-Fujairah-United-ArabEmirate.pdf

Dinas Kesehatan Padang. (2018). Profil Kesehatan Kota Padang Tahun 2018. https://dinkes.padang.go.id/

Farida, D., \& Yuliana, A. R. (2017). Pemberian Metode Kanguru Mother Care (KMC) Terhadap Kestabilan Suhu Tubuh dan Berat Badan Bayi BBLR di Ruang Anyelir Rumah Sakit Umum RA Kartini Jepara. Jurnal Profesi Keperawatan, 4(2), 99111. http://jurnal.akperkridahusada.ac.id/index.php/jpk/article/view/40

Ferber, S. G., \& Makhoul, I. R. (2018). The Effect of Skin-to-Skin Contact (Kangaroo Care) Shortly After Birth on the Neurobehavioral Responses of the Term Newborn: A Randomized, Controlled Trial. Pediatrics, 113(4 I), 858-865. https://doi.org/10.1542/peds.113.4.858

Field, T. (2017). Newborn Massage Therapy. International Journal of Pediatrics and Neonatal Health, 1(2), 54-64. https://doi.org/10.25141/2572-4355-2017-2.0054

Kementerian Kesehatan RI. (2018). Laporan Nasional Riskesdas 2018. Kementerian Kesehatan RI. https://www.litbang.kemkes.go.id/laporan-riset-kesehatan-dasarriskesdas/

Mazumder, S., Taneja, S., Dalpath, S. K., Gupta, R., Dube, B., Sinha, B., Bhatia, K., Yoshida, S., Norheim, O. F., Bahl, R., Sommerfelt, H., Bhandari, N., \& Martines, J. (2017). Impact of Community-Initiated Kangaroo Mother Care on Survival of Low Birth Weight Infants: Study Protocol for A Randomized Controlled Trial. Trials, 18(1), 1-10. https://doi.org/10.1186/s13063-017-1991-7 
Padila, P., Amin, M., \& Rizki, R. (2018). Pengalaman Ibu dalam Merawat Bayi Preterm yang Pernah Dirawat di Ruang Neonatus Intensive Care Unit Kota Bengkulu. Jurnal Keperawatan Silampari, $\quad 1(2), \quad$ 1-16. https://doi.org/https://doi.org/10.31539/jks.v1i2.82

Parsa, P., Karimi, S., Basiri, B., \& Roshanaei, G. (2018). The Effect of Kangaroo Mother Care on Physiological Parameters of Prematur Infants in Hamadan city, Iran. Pan African Medical Journal, 30, 1-8. https://doi.org/10.11604/pamj.2018.30.89.14428

Purwandari, A., Tombokan, S. G., \& Kombo, N. L. C. (2019). Metode Kanguru terhadap Fungsi Fisiologis Bayi Berat Lahir Rendah. JIDAN (Jurnal Ilmiah Bidan), 6(2), 38-45. https://doi.org/10.47718/jib.v6i2.815

Ramezani, T., Baniasadi, H., \& Baneshi, M. (2017). The Effects of Massage on Oxygen Saturation of Infants with Respiratory Distress Syndrome Treated with Nasal Continuous Positive Airway Pressure. British Journal of Pharmaceutical Research, 16(5), 1-7. https://doi.org/10.9734/bjpr/2017/32751

Saputri, H. D., Ernawati, D., \& Mufdlilah, M. (2019). The Effectiveness of Kangaroo Mother Care on Prematur Babies: A Scoping Review. International Respati Health Conference (IRHC). Yogyakarta. http://prosiding.respati.ac.id/index.php/PIC/article/view/83

Shah, H., \& Singaraveralan, M. (2019). Effect of Kangaroo Mother Care on Physiological Parameters in Low Birth Weight Neonates. International Journal of Health Sciences \& Research, 6(2), 791. https://doi.org/10.18203/23493291.ijcp20190731

Wati, R. C. R., Etika, R., \& Yunitasari, E. (2019). Pengaruh Perawatan Metode Kanguru terhadap Respon Fisiologis Bayi Berat lahir Rendah. Pediomaternal Nursing Journal, 5(2), 175. https://doi.org/10.20473/pmnj.v5i2.13333

Zahra, S. A., Radityo, A. N., \& Mulyono. (2018). Pengaruh Durasi Kangaroo Mother Care terhadap Perubahan Tanda Vital Bayi. Diponegoro Medical Journal (Jurnal Kedokteran Diponegoro), https://doi.org/10.14710/dmj.v7i2.21192

$7(2)$,

1182-1191. 